\title{
Prostitution in northern Central India: an ethnographical study of Bedia community
}

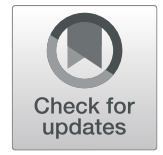

\author{
Usha Rana $\mathbb{D} \cdot$ Diwakar Sharma $\cdot$ Debarati Ghosh
}

Received: 28 August 2019/Accepted: 24 January 2020 / Published online: 03 March 2020 (C) The Author(s). 2020 Open Access This article is distributed under the terms of the Creative Commons Attribution 4.0 International License (http://creativecommons.org/licenses/by/4.0/), which permits unrestricted use, distribution, and reproduction in any medium, provided you give appropriate credit to the original author(s) and the source, provide a link to the Creative Commons license, and indicate if changes were made.

\begin{abstract}
Bedia community has been engaged in singing and dancing as 'rai' folk artists during the rule of monarchy in central India. It is mentioned in colonial literature that Bedia were a nomadic tribe and often engaged in criminal activities too. After the end of monarchy and change in the laws of the state, Bedias had nothing left for their survival. Therefore, Bedia women engaged in prostitution. Prostitution gradually became their primary source of livelihood. They trained their daughters to become prostitutes in the future. Girls were introduced into this profession as soon as they reached puberty. These girls worked at dance bars and also as professional sex workers in metro cities and villages. Their fathers and brothers worked as pimps/agents for the girls and their clients. Their families survived on the female's earnings. Bedia community inhabits many villages of Madhya Pradesh and central India. Since these villages are close to the city, customers find it easy to visit prostitutes regularly, and occasionally prostitutes also visit a customer on demand. Bedia women have been vulnerable victims of their community's traditional and cultural practices. Prostitution has a social stigma and is seen as immoral by other communities. Thus, Bedias are never accepted by other communities due to their disreputable professional practices. This paper deals with the historical understanding of the Bedia as sex workers and the

\footnotetext{
U. Rana $(\bowtie) \cdot$ D. Sharma

Department of Sociology and Social work, Dr. Harisingh Gour Vishwavidyalaya (A central university), Sagar, Madhya Pradesh 470003, India

e-mail: usharana21@gmail.com

D. Ghosh

Department of English, Arambagh Girls' College, Hooghly, West Bengal 712101, India
} 
contemporary situation of a particular community. The data was collected through ethnographic fieldwork from two villages (Habla and Fatehpur) and secondary sources. In particular, we shall discuss the socio-cultural aspects, family and kinship, lifestyle, the status of women, and domination of culture in this paper.

Keywords Bedia $\cdot$ Culture $\cdot$ Folkdance $\cdot$ Kinship $\cdot$ Madhya Pradesh · Prostitution · Trafficking

\section{Introduction}

The Bedia community of central India was earlier known as a denotified nomadic tribe. They chiefly engaged in singing and dancing to entertain the Kings and Zamindars (Land owners) of erstwhile India. They have been using traditional folk dance as a source of survival for their community. In the Mughal era, Bedia women entertained Mughal soldiers by their singing and dancing skills and also provided sexual pleasure to them. This tradition continued even under the patronage of the British armed forces (The Hindu 2016). In his historical work, Gathia has revealed that Bedia as well as other communities like Bachada, Kanjar, Koltas, Nat and Sansi had played a significant role in the sepoy mutiny in 1857 against the British crown, which later provoked the British authorities into including these communities in the 'Notified Tribes and Criminal Tribes list'. Their stay overnight at any village was supposed to be reported to the local administration and the police. Such repression deprived them of the essential sources of livelihood (Gathia 1999).

The community was identified with nomadic characteristics as they extensively travelled throughout the expanse of northern and central India for their artistic performances. They were invited during special occasions by the rich families and communities for performance. The talent they had in the performing arts was favourable to their survival in the erstwhile socio-cultural context. The Kings and Zamindars existing in the different regions of Madhya Pradesh, and other surrounding states kept up a demand for the Bedia women for dancing and the Bedia men for playing different musical instruments (Dholak, Tabla etc.). The subsequent changes in the state policy against nomadic communities in colonial duration was a major setback for the Bedia community in terms of their survival. After the war in 1857, the British government prohibited them from the right of ownership of agriculture land, and this cruel repression left them almost destitutes. Such a system continued throughout the entire British period (Gathia 1999). On one hand, the era of the Kings and Zamindars was on the decline after Independence while on the other, the demand for artistic performances tarted declining steadily. At the same time, Cinema and Television ${ }^{1}$ were emerging as new sources of entertainment (Mehta 2008; Saran 2012; Ingle, Hrislikesh 2017).

\footnotetext{
${ }^{1}$ Cinema and Television: Cinema consists of films produced in India in the Indian Film Industry, commonly known as Bollywood. In addition, regional language-based cinema also focusses on local and national issues. The film industry has been operational in India since 1912. It has played a vital role in entertainment as well as in social change.Television came to India in September, 1959. It is a popular form of entertainment in rural and urban areas as it provides several channels on drama, movies, news, sports, etc.
} 
Therefore, the Bedias were beginning to be ignored like other communities such as Bachada, Kanjar, Koltas, Nat, Naath, Sansi, Vasudev, etc., who had similar cultural practices. Being in the British authority's Notified Tribes and Criminal Tribes list, the Bedias were left landless and jobless after the decline of sovereignty.

Bedia community was also notified as a criminal tribe by the colonial state at the end of nineteenth and beginning of the twentieth century. The National Commission for Denotified Nomadic and Semi-nomadic tribes and the Ministry of Social Justice \& Empowerment of the Government of India have included Bedias in the Scheduled Caste category according to the Indian Constitution Scheduled Castes Order 1950 (June 30, 2008). Besides, studies by Non Government organizations with ActionAid ${ }^{2}$ (2008) indicated that Bedia and other communities could not get any benefit from the state in spite of being in the reserved category and they are suffering from poverty, insecurity, prostitution etc. As a result, Bedias take part in sex work and also many have chosen prostitution as a convenient occupation. They are, however, numerically inconsequential because they are scattered in large parts of Madhya Pradesh, Rajasthan, and Uttar Pradesh. A high density of Bedia population can be found in few districts of Madhya Pradesh including Guna, Gwalior, Morena, Rajgarh, Sagar, Shajapur, Sheopur, Shivpuri, and Vidisha. Initially, Bedias were inhabitants of the rural areas of all states, but in the late 1990s a definite trend can be seen amongst large proportions of the population to migrate to towns and cities. This migration had significant impact on the Bedias. Some of them migrated permanently but many decided to return to their villages. Recently some Non-Governmental Organizations (NGOs) (like Samvedna Bhopal; Sambhav Social Service Organization, Gwalior and Abhinaytosh Mahila Bal Vikash Samiti Sagar) report that Bedias are also involved in girl-child trafficking. A report published by the Department of Women and Child Development in 2004 reveals that Bedias were providing sex services to the customers of G. B. Road, Delhi (The Times of India 2006). Many cases have been reported where Bedia girls and women were rescued from metro cities like Delhi and Mumbai, and also from some parts of West Bengal (The Hindu, July 28, 2017).

\section{Review of literature}

A report published by Havocscope ${ }^{3}$ mentions that there are approximately 13,828, 700 people engaged in prostitution all over the world (Havocscope 2015). Many

\footnotetext{
${ }^{2}$ ActionAid: ActionAid India is part of a global federation and a full affiliate of ActionAid International that has presence in over 40 countries worldwide. Since 1972, the poor and the excluded have been at the centre of their discourse and actions in India. The Organization is governed by an independent General Assembly and a Governing Board. The vision of this organization is to root out poverty, patriarchy and injustice from society and to provide human dignity to each. https://www.actionaidindia. org/who-we-are/vision-mission/

${ }^{3}$ Havocscope: Havocscope is an online global infographic based data which shows black market activities like human trafficking for prostitution, organs, etc. It also provides data regarding countries which are the largest contributors to such illegal trade.It was founded in September 2013. According to the site, Havocscope gathers its information from both open-source and user-submitted statistics, and is not funded by Government agencies, foundations or industrial associations, ostensibly making the information more reliable. https://www.bizjournals.com/bizjournals/news/2014/08/26/the-1-8-trillion-blackmarket-is-almost-impossible.html
} 
researchers have devoted their efforts to highlight the reasons behind prostitution in the last 150 years (Benjamin et al. 1964; Bullough et al. 1978). Hughes mentions four reasons behind women's entry into prostitution (Hughes 2004). The first reason is sexual demand by man. The second reason is recruitment of women by different agencies such as brothel owners, traffickers, pimps and organized crime groups. The third important reason is the failure of state policies and legalization of prostitution. Hughes mentions cultural influence as the fourth reason for women entering into prostitution. He extensively discusses the pivotal role played by mass media in portraying prostitution as a means of quick money making.

Researchers from different parts of India have pointed out some significant factors leading women into prostitution. Chakraborty elaborates that in the second half of the nineteenth century in Bengal, women who could not be contained within the folds of social discipline were coerced into prostitution (Chakraborty 1963). Another reason for entry into prostitution was revealed by Tarachand. He examined the Devdashi tradition of women in rural south India (Tarachand 1991). In his work, he also states that "broken home and familial violence contribute to women's entry into prostitution." Furthermore, Menen and Karandikar argued that sex trafficking is another reason for entry into prostitution (Menen 2007; Karandikar et al. 2008). Their study has shown that sex trafficking has become a multimillion-dollar business at present.

Although prostitution is illegal in India, the country still has Asia's largest redlight area, namely, Kamathipura in Mumbai (Menen 2007; Karandikar et al. 2008) as well as other red light areas, such as G.B. Road (Delhi), Budhwar Peth (Pune), Meergunj (Allahabad), and Chaturbhujsthan, (Muzaffarpur) etc. The pervasiveness of prostitution cannot be accurately calculated because of the changes in the numbers of prostitutes getting involved in prostitution every year. According to the UNAIDS country report, there are 1.26 million female prostitutes in India (UNAIDS Country Progress Report 2010), and their number is increasing every year. According to the NCRB report, the government identified 5532 girls as victims of trafficking (Trafficking in Persons Report: India, 2018). The Ministry of Women and Child Development has shockingly reported that out of three million women involved in prostitution in the country, approximately $40 \%$ are children (Karandikar et al., 2013). Trafficking of children is managed by very organized channels with the sole objective of selling them to brothel keepers. Human trafficking is increasing day by day, and nearly $60 \%$ of the trafficked victims are minors (Sen et al. 2004). Pandey mentioned in her work that trafficking of children for sex work is a manifestation of deeper socio-economic problems (Pandey 2018).

Another study by Sithannan found that certain communities like Bedia, Benchara, Rajnat who practice institutional prostitution have been actively participating in sex work since the ancient past to the present (Sithannan 2006). Prostitution has been identified as a convenient familial occupation among the Bedias (Agrawal 2008; Agrawal 2018; Pandey 2010; Ray 2008; Sen et al. 2004) but their occupation takes away their respectability or social status. The queerness of the Bedia community is that they themselves train their girls to be prostitutes. Traditionally, the elder daughter must participate in prostitution. Community structures and guides institutions like family, marriage, and kinship to act accordingly. In Sagar 
district, there are several villages which are inhabited by the Bedia population, such as Pathriya, Mehar, Maneriya, Rahatpur, Banda, Gadakota, Madwara, Bamuriya, Karyiya Fataka, Fatehpur, Habla and so on.

\section{Methods and field view}

In this study, we shall discuss the cultural practices of the Bedia community based on ethnographic fieldwork. Over 6 months (from November 2018 to April 2019) the data was collected through series of interactions, in-depth interviews, and observation of the Bedia community of Habla hamlet and Fatehpur village in the Sagar district of Madhya Pradesh. Habla hamlet has 100\% habitation of Bedia population, while Fatehpur village has a mixed habitation of Bedia and other castes. Fatehpur was selected in order to understand the relations between the Bedias and other communities. We chose a group of key individuals such as retired prostitutes, working prostitutes, pimps (male family members) and adolescent girls to collect key information. The long term observations and interactions helped us to understand the Bedia community in a profound and collective manner. Also, secondary data was used to provide comprehensive information about the history and culture of Bedias. Further, demographic data was generated with the help of local government and other local institutions.

\section{Findings and observations}

This study was conducted in two villages (Habla and Fathepur) of Sagar district in Madhya Pradesh. Sagar district of Bundelkhand region has been facing different problems, for example, drought, poverty and illiteracy (Gupta et al. 2014; Human Development Report of Bundelkhand 2012). Habla hamlet is a small isolated area which comes under the administration of Luhari village panchayat (Local Government) located only $24 \mathrm{kms}$ away from the main city. The total population of this settlement is 615 and within the radius of $7 \mathrm{kms}$, it is very hard to find any habitation, and this supports the fact that other communities do not socially interact with Bedias. Five decades ago, 3 Bedia families of Habla hamlet migrated to Fatehpur village, where they settled permanently, and still their population is 69 only. In Fatehpur, Bedias reside together since they have no social interaction with other castes. Although, other communities have adapted to cultural changes, Bedias still remain socially and economically weak. The Bedia families have no reliable sources of income and hence, unmarried women of the family are compelled to offer sex services within the village as well as outside the district. Changes in the sources of entertainment compelled the Bedia community to neglect their traditional 'rai' folk dance. However, girls and women still make artistic performances to attract new clients in the region. Recent studies have revealed that Bedia women and girls are being made available to international customers for sex services through international agents and local pimps (Agrawal 2003; Agrawal 2006; India Today 2013). 


\section{Socio-economic and cultural features of Bedia community}

During a discussion with a senior male member of Bedia community of Fatehpur village regarding their tradition and culture, he said that ("Hum log kalakar hai, isliye hum mata Saraswati ke putra hai") they are artists and therefore they are the sons of Goddess Saraswati (Saraswati is the Hindu Goddess of knowledge and art). Bedias perform their folk dance in different social and cultural programs like the religious 'Kumbh' fair (The Hindu Business Line 2018). They have been recognized by several national and regional societies for their 'rai' folk dance. The senior man continued that (Humare purvajo ko paristhitiyon ke karan us samay vaishyavritti aapnani pari, British sarkar ne humare saath galat kiya, humare paas khane ke liye kuchh nahi tha. Isliye, humari mahilayo ne pariwar ko samarthan kiya, or ye humari pahachaan ban gai. Swatantra Bharat sarkar ne bhi humre liye kuch nahi kiya or aaj jo bhi humare paas hai keval vaishyavritti ke karan hai, isliye hum vaishyavritti nahi chhod sakte) their ancestors had to adopt prostitution because of the contemporary circumstances. The British government treated us wrongly. We had nothing to eat. Therefore, our women came out to support their families and such practices became our identity. Even the independent Government of India did not do anything for us and whatever we have today is because of prostitution, so we can't leave prostitution. Following Table 1 will help to understand the socio- demographical profile of both villages.

Field data focusses on the sex ratio: there are more women than men. There is a significant difference in the proportion. The main factor for this disparity is that brides comes from outside the community while women from the Bedia community are not allowed to marry. Percentage of illiteracy is high in the community and this leads to unemployment and poverty. It is difficult to know their exact income because it is not fixed. Authors have only been able to find out as per the current situation. Table 1 shows low income population percentage is high in the community. But prostitutes sometimes receive many gifts from their clients incuding land. Therefore, Bedia families have been able to improve their standard of living a little. They live in small-cemented houses with regular amenities like air coolers, televisions, mobile phones, and many even have motorbikes. The families in which two or more girls are engaged in prostitution have been able to buy tractors. Some of Bedia families invest their money in buying agricultural land, vehicles and in construction or renovation of their houses. Three Bedia families have houses in Sagar city. From discussion with the Bedia families, we found that families without girl child considered themselves unlucky.

The Bedia community justifies prostitution. According to them, sex work is a culturally and socially accepted form of earning or livelihood. But the derogatory label of prostitution has stigmatised the entire community and hence they are treated as 'untouchables' and 'immoral people' by the society. This discrimination can be observed in the social isolation of Bedia children by other castes. The other castes in Fatehpur village do not permit their children to play with Bedia children. Humiliation at the hand of other castes has become a routine as they are constantly belittled for their profession. Their women are known as 'Bedni', a term pejoratively used for abusing the immoral woman of the Bedias. Moreover, the children 
Table 1 Socio-demographic characteristics of respondents

\begin{tabular}{|c|c|c|c|c|}
\hline Socio-demographic variables & $\mathrm{N}_{1}=615$ & $\mathrm{~N}_{2}=69$ & $\mathrm{~N}_{1}+\mathrm{N}_{2}=N=684$ & Percentage \\
\hline \multicolumn{5}{|l|}{ Population } \\
\hline Male & 286 & 33 & 319 & $46.63 \%$ \\
\hline Female & 329 & 36 & 365 & $53.36 \%$ \\
\hline \multicolumn{5}{|l|}{ Marital status } \\
\hline Married & 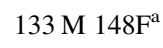 & $15 \mathrm{M} 15 \mathrm{~F}$ & 311 & $45.46 \%$ \\
\hline Unmarried & $151 \mathrm{M} 158 \mathrm{~F}$ & $18 \mathrm{M} 20 \mathrm{~F}$ & 347 & $50.73 \%$ \\
\hline Divorcee & $00 \mathrm{M} \mathrm{04F}$ & $00 \mathrm{M} 00 \mathrm{~F}$ & 04 & $0.58 \%$ \\
\hline Widow/Widower & $02 \mathrm{M} 19 \mathrm{~F}$ & $00 \mathrm{M} 01 \mathrm{~F}$ & 22 & $3.21 \%$ \\
\hline \multicolumn{5}{|l|}{ Education Level } \\
\hline Illetrate & 398 & 51 & 449 & $65.64 \%$ \\
\hline Primary & 180 & 09 & 189 & $24.63 \%$ \\
\hline Secondary & 22 & 05 & 27 & $3.94 \%$ \\
\hline Higher Secondary/Above & 15 & 04 & 19 & $2.77 \%$ \\
\hline \multicolumn{5}{|l|}{ Livelihood Source $^{\mathrm{b}}$} \\
\hline Prostitution & 89 & 12 & 101 & $14.76 \%$ \\
\hline Agriculture & 16 & 05 & 21 & $3.07 \%$ \\
\hline Prostitution/Rai and Agriculture & 482 & 46 & 528 & $77.19 \%$ \\
\hline Others & 28 & 06 & 34 & $4.97 \%$ \\
\hline \multicolumn{5}{|l|}{ Income Monthly ${ }^{\mathrm{b}}$} \\
\hline Rs. 5000/- & 300 & 29 & 329 & $48.09 \%$ \\
\hline Rs. $5001 /-$ to $10,000 /-$ & 132 & 12 & 144 & $21.05 \%$ \\
\hline Rs. $10,001 /-$ to $15,000 /-$ & 122 & 12 & 134 & $19.59 \%$ \\
\hline$>$ Rs. $15,000 /-$ & 61 & 16 & 77 & $11.25 \%$ \\
\hline
\end{tabular}

$\mathrm{N}$ denotes total number of population. $N_{1}$ Habla, $N_{2}$ Fatehpur, $F$ female, $M$ Male

Source: Data from local government samagra state population register, 2016 and fieldwork 2018-19

${ }^{a}$ Including the cases where their husbands are not living with them

${ }^{\mathrm{b}}$ Livelihood source and monthly income are the household data mentioned in the proportion of family members

of Bedia women are referred to as 'Bedni ke' (child of Bedia women). As a result, many Bedia children have left schools and willingly remain illiterate. At present, one Anganwadi (Government childcare center) and one primary school has been functioning there. If any Bedia child wishes to continue his/her study, then, he/she has to go to Luhari village. Luhari village is a part of the same panchayat but located far from the settlement. Therefore, many children are not able to continue their studies. However, a few Bedia women are trying to provide proper education to their children, especially sons. For instance, one Bedia woman from Habla settlement had left her son at a relative's house so that he was able to receive a good primary education. Later, he was sent to a boarding school (Navodya Government School) to complete his schooling, and then he enrolled in graduation course at the Banaras Hindu University (a Central University), Varanasi (U.P.). The mother stated that since her son wanted to be a Collector (Indian administrative officer), she and her daughter sent him ten thousand rupees per month for his 
coaching. Another example can be seen in Fatehpur village where a prostitute has enrolled her son in a private college at Sagar city.

\section{Family structure}

The Bedias have extended families due to their occupational requirements. Three or four generations are usually found to be living together. There are three categories of women in the Bedia community, two categories of children and Bedia men. The first woman is sister or daughter. They cannot marry and have to learn their traditional 'rai' folk dance and enter prostitution as they grow up and the whole family depends on their earnings. The second type of woman is the wife of Bedia men who do not get involved in prostitution. Generally, they do not belong to the Bedia clan. They only look after household duties. Another type of woman is the retired sex worker who lives with her family after retirement and remains involved in all internal family matters.

Children are also of two categories-one born from the union of Bedia men with their wives and other from the union of Bedia women with their clients. The second type of kids are biological kids of their clients, but they are not socially responsible for these children. These kids grow without their father's name and care. Schools deny them admission in the absence of the father's name. However, some natives informed us that often grandparents give their name to these kids. One individual told us that the Madhya Pradesh government has allowed the Bedia women's kids to be enrolled in schools without their father's name. But, a large number of Bedias are not aware of this Government order. Most of the people complained that they had no identity cards because of the lack of the father's name. It has been found that there are only 300 Voter's Identity cards although there are 615 inhabitants in the Habla settlement.

Generally, Bedia men are not morally, socially or financially accountable to their families. Like other patriarchal societies, Bedia males also dominate females by excluding them from all forms of decision making.

\section{Marriage and kinship}

Gender-based discrimination can also be seen in the Bedia community. Only the male members of the community are allowed to marry outside the community. Bedia women compelled to remain unmarried and enter into the profession of prostitution. The groom's family offers a substantial amount to the bride's family as 'bride price'. This amount is paid by their prostitute sisters and if they fail to arrange such amount, they are denounced by their family and the community. Bedia men have the freedom to test and ensure the chastity of their chosen spouse before marriage. During the interaction with people at Habla, it was emphasized (Hum chokho pesa dete he to kumari hi to lege) that since we pay a handsome sum of money so we will accept only a virgin. Table 1 clearly shows that not a single male divorces his wife. On the contrary, many Bedia men remain unmarried due to heavy bride price. 
The girls enter into prostitution at the very tender age of 13 to 16 years and continue up to the age of 32 to 36 years. Some of the girls are sent to metro cities to work as bar dancers and professional sex workers. A few of them earn as much as Rupees 14,000 to 45,000 per month, but this is not a fixed amount. Girls who live in rural areas do not earn as much. Many cases have been reported where these girls have even been trafficked outside the country. These girls retire and return to their villages by the age of 32-36 years. However, now they require patronage to meet their financial requirements. In some cases, they are compelled to accept their own clients of the past as husbands. They even wear all symbols of a married woman (Mangalsutra, Bichua, and Bindi etc.) like traditional Hindu wives. Some of the retired prostitutes choose to marry persons from other communities. Interestingly, Bedias says that, they allow virgin girls to marry men outside the community but their number is invisible.

Status of Bedia woman and man

Patriarchal practices characterize the northern and central Indian socio-cultural setup. The birth of a girl child is still considered a misfortune, resulting in an alarming decline in the sex ratio. Gender-based discrimination, violence, inequality and female foeticide are the common evils in this area. However, Bedias prefer and admire girls. They celebrate the birth of a girl child. Pregnant Bedia women frequently go through sex-determination tests to identify sex of the fetus in order to avoid the birth of a male child. It is alleged that the Bedia community in Rajasthan prefer abortion of the male fetus. They do so, due to severely limited job opportunities and lack of resources for the male members of the Bedia community (The Hindu 2016). On the contrary, girls are seen as sources of income for the family in the future. They are expected to join the occupation once they attain puberty. This tradition has been continuing since the last many generations in the Bedia community. Occasionally, even pre-pubescent girls are groomed for prostitution. These girls are persuaded to watch pornography and blue films by their mothers and aunts. Their families often use medicines and injections such as the growth hormone oxytocin (available in medical stores) to ensure their development as an adult faster than usual (The Hindu Business Line 2017). The introduction of girls into prostitution is known as 'nath utarna' or 'sardhakwana' ritual. This ritual marks the entry of a particular girl from the threshold of girlhood into womanhood, after which the girl is considered ready for prostitution. Interestingly during the interviews, often the members of the Bedia community asserted that they were engaged only in singing and dancing (Acharya 2011). They did not seem comfortable in collectively accepting their participation in prostitution. After retirement, the women come to stay with their families. In some cases it has been observed that the retired prostitutes work as farm labourers.

\section{Case study 1}

A 67-year-old Bedia woman who had been involved in prostitution said in the local language that at the time when I was able to earn, all family members 
respected me. I started to earn at the age of 13 and took care of all the members. Now nobody looks after me. I live in one corner of the house; even there is no money for medicine. I have no children. If I had them then they would have done something for me. 10 years ago, I used to work as a labourer in the agricultural field for survival but now I am unable to do the same anymore. Before that, my man (client with whom I was associated during prostitution) financially assisted me. Now, I do not know when I shall die.

\section{Case study 2}

In Fatehpur village, one prostitute told that she is 34-year-old woman working since the age of 14 years in this occupation. She is the mother of two kids- one son and one daughter. Both are studying in Sagar city. She shared her pain regarding how her clients frequently misbehaved with her. She also shared her emotional attachment with one client, and when he did not return, how sad she felt. She said that her kids do not know the name of their biological father. She discussed her difficulty in enrolling her kids in school and college. She remarked that now I am reaching the age of retirement. After that, I do not know; how my home will be financially managed. My father wants me to replace my position with my daughter, who is now only 11 years old, but I don't want that.

Wives of Bedia men do not have the freedom. They do all the domestic work and become victims of domestic violence. Due to the payment of a massive bride price by the groom's family, they are treated as bonded labourers. Bedia men work as pimps and agents for their sisters and daughters. They are lethargic and use their sisters and daughters to survive. They learn no skills to earn their livelihood and are found to be blaming the social system for their problems. But, now-a-days, some Bedia men are trying to contribute to the family income though their efforts are not sufficient. They are buying agricultural land and tractors from their women's earnings to get engaged in agricultural work. It has also been observed that few Bedia women are encouraging their male child to get educated.

\section{Domination of tradition}

Traditional practices of a particular culture coerce the natives into following it without questions. Though discourses are started later regarding the fundamental basis of such practices, in the mean time, historical reference is added to the practices as they are followed from one generation to another. Similarly, prostitution has been accepted as a tradition amongst the Bedia community. The female members are not given the freedom to dream of education, career or a respectable marriage. Their bodies are used as a commodity to earn for the family and the community. The dispirited Bedia women elucidated (Ye sub bahut pehle se ho raha he or muje bhi wahi karna hoga. Mere pariwar ne mujse jo karne ko kaha, maine kiya.) that these practices have been going on since a long time and that I must also do the same. I did what my family asked me to do. Another male member argued (Pita hone ke nate me hi bataunga ki meri beti kya karegi, or hum apni parampara 
ke anusaar kar rahe he.) that as a father, it was his prerogative to decide what his daughter would do and that he was only following tradition.

The Bedia community has formed an arrangement according to which the girls are made to learn essential skills of their trade from their elder sisters and aunts. They are trained in folk dance to attract customers. They must learn to do makeup and wear suggestive clothes. Hence, the acceptance of the traditional norms becomes a part of the normal growing process for these young innocent girls. The extraordinary point is that the same age which is considered to be suitable for these girls/children to enter this adult profession, is not supposed to be appropriate for them to be able to take their own decisions in life. Although, many prostitutes said that (Veshyaavrtti se me aapne liye kama sakti hu) they could earn for themselves by prostitution, some of the others exclaimed (Ye humari kismet he) that it was their destiny. One senior Bedia woman emotionally pointed out that 'our body is not ours, but what can we do, this is our tradition' and continued that 'we do not think about it anymore; this is our destiny, and nobody can change it.' The violation of the women's rights and their emotions has for long been an accepted practice amongst the Bedia community. In spite of being the crucial earning members of the family, women are controlled by the patriarchal norms.

\section{Living standard and life cycle}

Generally, in both the chosen villages, people do not like to visit Bedias. Bedias, however, visit the city market for their daily needs. They are Hindus and worship all Hindu gods including some local gods. They visit temples regularly. Usually, Bedias sing classical, romantic and religious stories in the form of songs during 'rai' folk dance. Some women and kids wear pendants containing pictures of Lord Krishna, Hanumana, and Goddess Durga. Bedias speak Bundelkhandi language (a regional language of Hindi). They eat both vegetarian and non-vegetarian dishes. The men drink alcohol regularly while the women take gutka (chewing tobacco). Any special occasion is not considered to be complete without alcohol. Most of the Bedias spend their money in purchasing expensive clothes, alcohol, bikes, and mobile phones. The first day of the girl entering prostitution is celebrated as a grand function in the community. Traditionally, Bedias never believe in saving for the future. But now they have started investing in agricultural lands and concrete houses. A few houses are equipped with modern devices like television, music system, air cooler, radio etc. One retired woman has claimed that mobile phone has made their life easier as the girls can now contact their family members and clients directly.

However, the Bedias are facing several grave problems such as illiteracy, domestic violence and suffering from health issues like tuberculosis, sexually transmitted diseases and HIV/AIDS. A large proportion of the Bedia population does not want to go to school. Many children dropout of school between the 3rd and the 5 th standard. One woman made a solemn statement that (Humara dhanda dusro ke liye samajik kalank he) their occupation is a social stigma for other people. Their children are teased by kids from other communities. To overcome this 
discrimination, few parents have started sending their children to schools in the cities for education. One woman pointed out that (Humare bachche school me aapne ko Bedia nahi batate) their children do not reveal their identity as Bedia in school.

Domestic violence is a common problem for the wives of Bedia men. However, Bedia sisters and daughters are protected and treated well because of being the earning member of the family. However, if they try to deny entering into prostitution, they have to face violence. Bedia men spend their money on alcohol which lead to their untimely and premature deaths as a result of liver infections and tuberculosis. This is one of the cause to down sex ratio of male in bedia community (Table 1) On the other hand, women's health is ruined by sexually transmitted infections and other related diseases. Although Bedia people claim that the government has not done anything for them, yet Bedias are included in the scheduled caste (SC) category. They are unable to get reservation benefits because of their own illiteracy.

\section{Discussion}

Bedia women have been suffering from prostitution as a result of their customary practices which are supported by their own families. Prostitution is accepted as a normal practice. Even adolescent girls accept it as a part and parcel of their life. Later, when they become mature, it is too late to change their lives as it is next to impossible that they would be accepted again in polite society. Such traditional and cultural practices keep on encroaching on their rights and victimizing them. The practice of prostitution has exploited human rights for centuries and still has relative dominance in the Bedia community. The traditional practices and some other factors such as illiteracy, lack of awareness, lack of resources, and opportunities are amenable for the women's entry into prostitution.

Contemporary global society has succeeded in recognizing rights such as social justice, social security, social welfare, human rights, and non-discrimination for all. There is some developmental work done by the state administration of Madhya Pradesh, India. One of the former bureaucrats, Harsh Mander, who is now working with several Non-Government Organizations, has talked of the difficulties of the Bedia women on public platforms and worked for change in the Bedia community (The Hindu 2001). Madhya Pradesh State Government has started the Jabali Yojna since 1992 for the eradication of socially accepted prostitution, (The Hindu 2000). This scheme attempts to eliminate the commercial and sexual exploitation of the women in the community and mainly focusses on the children of specific communities in the state. However, such efforts could not achieve the expected success as the institutional support of prostitution was the biggest drawback. Moreover, the Government tried to rescue prostitutes and handed them over to their families. Unfortunately, such families again sent their women for the same work. Hence, the State Government has failed to ensure the mainstreaming and rehabilitation of the Bedia community.

Several NGOs are working with Bedia and other similar communities but have been unable to eradicate prostitution until now. However, few instances show a ray 
of hope in the right direction. For instance, two sisters from the Bedia community approached the police in Rajgarh district, Madhya Pradesh, pleading to rescue them from their community's traditional occupation of prostitution. These fatherless girls lived with their mother and went to school, but their relatives and community members were forcing them into prostitution (The Times of India 2017). These girls tried to overcome exploitation at the hands of their community. Another instance is the beginning of long term intervention in Bedia's traditional structure at Basai village in Agra, Uttar Pradesh, by a Non-Government Organization. Now $90 \%$ of families of the Bedia community do not force their daughters into this profession. Moreover, the male members have also started to work for the survival of the family (The Times of India, Dec. 27, 2015).

In Habla settlement and Fatehpur village, many prostitutes stated that they consider it their destiny that they are in this occupation and though they have been suffering they are unable to change it. However, they do not wish their girls to enter in the same occupation. They have also started focussing on the education of their sons so that they shall be able to earn for their families in the future, and their daughters can then lead a normal and respectable life. However, the males in the same community do not agree with females; they use historical reference, patriarchal influence and cultural hegemony through institutions to force girls into prostitition. Hopefully, long term intervention can change the traditional stereotypes and cultural practices in the community which, in turn, can help to change the collective mindset of the society. Government and Non-Governmental organizations should have to come in the forefront to take a stern initiative to stop the malpractice. Education and new vocational skills for the new generation, availability of job opportunities for all and proper rehabilitation of prostitutes will be a good step in abolishing prostitution.

\section{Conclusion}

Bedia women have been a victim of institutional prostitution since long. Colonial state policy, poverty, social institutions, cultural history, patriarchy and sluggish nature of male are responsible for same. Apparently the problem may seem local but links at the ground level are responsible for creating a vicious chain for girl-child trafficking. Bedia pimps and agents buy girl children from poor families and sell them in red-light areas in India as well as in the international market. However, a more active role is expected from the Government and other organizations for its total eradication. A long term intervention can certainly change their lives. The Bedia community should be encourage to develop their folk art of 'rai' dance which can establish them as artists in the national and international arena in the future. Their heritage can be utilized as a source of livelihood and can give them their identity and dignity. This historical practices of victimization of women can be rooted out through multiple interventions by the Government through legal efforts, special opportunities for such communities and adoption of effective policies. 


\section{Publisher's Note}

Springer Nature remains neutral with regard to jurisdictional claims in published maps and institutional affiliations.

Acknowledgements Not applicable.

\section{Authors' contribution}

UR carried out the fieldwork and investigations, and drafted the overall manuscript. DS helped to draft the manuscript. DG improved the English language. All authors read and approved the final manuscript.

\section{Funding}

Not applicable.

\section{Availability of data and materials}

Available from the author upon request.

\section{Ethics approval and consent to participate}

Not applicable.

\section{Consent for publication}

Not applicable.

\section{Competing interests}

The authors declare that they have no competing interests.

\section{References}

Acharya, Arun Kumar. 2011. Impact of cultural and religious practices of prostitution on the trafficking of women in India. Trayectorias 14: 95-114.

Agrawal, Anuja. 2003. Kinship and trafficking the case of the Bedia community. Canadian Women Studies 22: $131-135$.

Agrawal, Anuja. 2006. Migrant women and work. New Delhi: Sage Publication.

Agrawal, Anuja. 2008. Chaste wives, and prostitute sisters: Patriarchy and prostitution among the Bedias of India. New Delhi: Routledge Publication. 
Agrawal, Anuja. 2018. Situating the law on prostitution/sex work in India. E-journal of the Indian Sociological Society 2: 3-20.

Benjamin, Harry, et al. 1964. Prostitution and morality: A definitive report on the prostitute in contemporary society and an analysis of the causes and effects of the suppression of prostitution. New York: Julian Press.

Bullough, Vern, et al. 1978. Prostitution: An illustrated social history. New York: Crown Publishers.

Chakraborty, Usha. 1963. Condition of Bengali women: Around the second half of the 19th century. Calcutta: Published by Author.

Gathia, Joseph. 1999. Child prostitution in India. New Delhi: Concept Publishers.

Gupta, Anil Kumar et al. 2014. Bundelkhand Drought: Retrospective analysis and way ahead. https://nidm. gov.in. Accessed 10 Mar 2019.

Havocscope. 2015. Prostitution: Prices and statistics of the global sex trade. http://www.havocscope.com/ prostitution-statistics. Accessed 01 May 2019.

Hughes, Donna M. 2004. Best practices to address the demand side of sex trade trafficking. https://childhub.org/en/ child-protection-online-library/best-practices-address-demand-side-sex-trafficking. Accessed 01 May 2019.

Human Development Report of Bundelkhand. 2012. NITI Aayog-UNDP project on Human Development: towards bridging inequalities. https://www.undp.org. Accessed 10 Apr 2019.

India Today. 2013. Sex as trade and tradition: For Bedia families, sex is a family business where young girls engage in prostitution with the consent of the community. https:/www.indiatoday.in/magazine/society-the-arts/story/ 20131028-sex-trade-and tradition-family-business-Bedia-families-768084-1999-11-30. Accessed 05 May 2019.

Ingle, Hrislikesh. 2017. Prabhat studios, early Marathi cinema and respectability. Economic \& Political Weekly 52: 43-48.

Karandikar, Sharvari, et al. 2008. My one-way ticket to Kamathipura. Rights of sex workers comprised. Research for Sex Workers 10: 12-15.

Karandikar, Sharvari, et al. 2013. A qualitative examination of women involved in prostitution in Mumbai, India: The role of family and acquaintances. Int Soc Work 56: 496-515.

Mehta, Nalin. 2008. Television in India Satellites, politics and cultural change. New York: Routledge Publications.

Menen, Rajendar. 2007. Karma sutra essays from the margin. Canada: Saga Books.

Pandey, S.P. 2010. A study of children dependent on prostitutes in selected areas of Uttar Pradesh. Lucknow: Pt. G. B. P. Institute of Studies in Rural Development.

Pandey, Sonal. 2018. Trafficking of children for sex work in India: Prevalence, history, and vulnerability analysis. E-journa l of the Ind ian Sociological Society 2: 21-43.

Ray, Nilanjana. 2008. Vulnerability to human trafficking: A qualitative study. Retrospective Theses and Dissertations 17 https://openscholarship.wustl.edu/etd_restrict/17.

Saran, Renu. 2012. History of Indian cinema. Publisher. Diamond Pocket Books: New Delhi.

Sen, Sankar et al. 2004. A report on trafficking in women and children in India 2002-2003. NHRC-UNIFEM-ISS Project, http://nhrc.nic.in/sites/default/files/ReportonTrafficking.pdf.

Sithannan, Veerappan. 2006. Immoral traffic-prostitution in India. Chennai: Jeywin :Publications.

Tarachand, K.C. 1991. Devadasi custom. Rural social structure and flesh markets. New Delhi: Reliance Publishing House.

The Hindu, 2000. Back to basics. https://www.thehindu.com/todays-paper/tp-opinion/back-to-basics/article18702654.ece. Accessed 10 July 2019.

The Hindu. (2001). Style over substance. https://www.thehindu.com/features/ metroplus/Style-over-substance/ article14388236.ece. Accessed 10 July 2019.

The Hindu. (2016). Dance, dance, dance. https://www.thehindu.com/news/national /other-states/Dance-dancedance/article11796369.ece. Accessed 25 June 2019.

The Hindu Business Line. (2017). Childhood for sale. https://www.thehindubusinessline .com/blink /know/ childhood-for-sale/article9790915.ece. Accessed 01 July 2019.

The Hindu Business Line. (2018). Apsaras descend for the devotee. https://www.thehindubusines sline.com/ blink/shoot/apsaras-descend-for-thedevotee/article9 850195.ece. Accessed 20 June 2019.

The Times of India. (2006). A Rajasthan village where prostitution is tradition. https://timesofindia.indiatimes.com/india/A-Rajasthan-village-where-prostitution-is-tradition /articleshow/1717444.cms. Accessed 20 June 2019.

The Times of India, (2015). From dance bars to school: Bedia girls on reforms path. https://timesofindia. indiatimes.com/city/agra/From-dance-bars-to-school-Bedia-girls-on-reforms-path/articleshow/50338469. cms. Accessed 20 June 2019. 
The Times of India. (2017). The Bedia girls won't dance no more. https:/timesofindia.indiatimes.com/city/ agra/The-Bedia-girls-wont-dance-no-more/articlesho w/50336773.cms. Accessed 01 July 2019.

Trafficking in Persons Report: India. (2018). https://www.state.gov/reports/2018-trafficking-in-persons-report/ india. Accessed 15 July 2019.

UNAIDS Country Progress Report. (2010). http://www.unaids.org/en/dataanalysis/monitoringc ountryprogress/progressreports4/2010 countries/india_2010. Accessed 25 May 2019. 